\title{
Flora of Plymouth Sound and Adjacent Waters. Preliminary Paper.
}

\author{
By \\ T. Johnson, B.Se., \\ Professor of Botany in the Royal College of Science, Dublin.
}

A Government grant by the Royal Society enabled me to spend the months of August and September of 1889, in the investigation of unknown or obscure points in the marine algæ, in the Laboratory of the Marine Biological Association, Plymouth. One of my chief objects was to obtain such material of the various members of the Gigartinacex, of Spyridia, Stenogramme, and other genera, as would permit me to make a detailed examination of the development of the fruit (cystocarp) from the earliest stage to maturity. Several of the genera required were very rare or of unknown locality, and in many cases only to be found by dredging. In searching for these, new weeds, or new localities for known weeds, were met with, and it seemed to me the notes I made would be of use to algologists. Cocks, Hore, Boswarva, Gatcombe, \&c., and of late years Holmes,* have combined in their work to give a very full account of the marine algæ to be met with without the use of the dredge. For twenty years Cocks, I am told, did not miss a single low tide at Plymouth (or, if not, Falmouth). Up to the present our knowledge of the weeds of Plymouth has been derived almost entirely from shore-hunting, some of the rarest weeds being described as washed ashore, so that it was a question as to whether such weeds were locally established or merely "drift" specimens. In 1867 Boswarva published his Flora of Plymouth Sound in the Transactions of the Plymouth Athenæum, his catalogue being compiled from the discoveries of himself, Cocks, \&c. This list appears word for word in the Marine Biological Association Journal, No. 2, 1888. I am permitted by $\mathrm{Mr}$. Holmes to say that through a misunderstanding he is stated to give the names of eight additional species. It is only fair to the early algologists to point out that five at least of

* Through the courtesy of Mr. Holmes I have seen a list of species added by him to the Flora of Devonshire (Journal of Botany). I believe I am not overstating the case in saying that he has added one hundred species of algæ to the British Flora, some new to science. 
these were known to occur in the Sound in Boswarva's time. I shall suppose readers of the following pages to be familiar with the abovementioned catalogue, and to have a general knowledge of the Sound, from the Admiralty chart or otherwise. My chief objects when dredging were to see if the rare "washed ashore" weeds had any local habitat, if there was a well-marked connection between the east and west shores of the Sound by extra-tidal weeds, and to work out as fully as possible the extra-tidal flora. For the accomplishment of these objects it was necessary to work as near in to the shore as it was safe* to take the steamer ("Firefly") or the sailing boat ("Mabel ").

\section{Disturbing Influences in the Flora.}

Many disturbing influences have been at work since the date of Boswarva's catalogue, the weeds mentioned by him as occurring in particular localities being in many cases no longer to be met with, or only after very diligent search. Of these influences it will be well to notice a few.

The Breakwater.-This immense structure, completed in 1841, and extending for more than a mile across the Sound, must have had an impoverishing effect on the flora of the Sound internal to it. This is more especially seen in the eastern inlets. Rum Bay, Jennycliffe Bay, Batten Bay, protected by the Breakwater from the south-west gales, are also cut off, to a large degree, from communication in a south-west direction with the English Channel and the Atlantic Ocean, and, to this extent, deprived of the spores of weeds brought by south-west currents. Batten Bay has been still further denuded by the presence, since 1882, of Batten Pier, and, spite of the presence of several rare weeds, has changed from a locality rich in seaweeds to one of the poorest, the effects of town and harbour refuse on the seaweeds in these eastern bays being also very marked.

Refuse.-No doubt in the Sound, as elsewhere, the increase, with population, of refuse has had a deteriorating effect on the algæ, as e.g. in Batten Bay just cited. I was given to understand that during recent years the bed of the Laira has been raised five feet by the deposit of clay and general refuse from the china clay works on Dartmoor. This cannot but have an effect on the weeds of the Laira and the Cattewater. Batten Pier seems to tend to drive the water from the Cattewater, Laira, and Sutton Pool, westward, where, between the west end of Batten Pier and the ladies'

* I have much pleasure in acknowledging the great help I received from the fisherman to the Laboratory, W. Roach, without whose astonishing knowledge of the submerged rocks, \&c., it would have been impossible for me to do as I did. 
open bathing-place below the Hoe, the weeds are not so clean as in many other localities.

Firestone Bay.-The shore of this bay is being completely altered. The west part of the beach has been converted into an artificial stony embankment, on which now the commonest of weeds grow. It seems useless to look for the rare forms at one time found on its shores-Crouania attenuata, Spyridia filamentosa, Chrysymenia rosea, Striaria attenuata. Blasting is in full operation in the eastern part of the bay, with a conseqnent disturbance of the flora.

I would record here my great indebtedness to Mr. G. C. Bourne, the Director of the Laboratory, for the liberal use I was allowed to make of the resources of the Association for the supply of material. I could not have wished for more use, * having regard to the needs of the zoologists engaged in investigations in the Laboratory. I cannot hope to give an adequate idea of the innumerable opportunities for research. The brackish waters, with their accompanying mud-banks, furnish many plants needing investigation; Plymouth waters were long ago pointed out by Harvey as pre-eminently a habitat of the genus Callithamnion. There is quite enough material obtainable for the study of the unknown life-history of the plants Dictyotacex, Ectocarpus, Tilopteris Mertensii, Pylaiella, Mesogloea, Punctaria, Arthrocladia villosa, Sporochnus pedunculatus, Asperococcus, Bryopsis, Codium, \&c., and many Florideæ (until the great work on the Florideæ by F. Schmitz appears it is impossible to say what requires to be done in this group). One or two examples may be given. Arthrocladia villosa, described as occurring in Firestone Bay only, I found in at least seven other localities, and in several places in quantity. Stenogramme interrupta is a plant of which very little is known. There is doubt even as to the position of the tetraspores; male organs are unknown, and there is no description of the procarpia or fruit formation. I have got material in which I am able to come to definite conclusions on all these points.

" The greater part of my work was done by the help of the dredge in the "Firefly," "Mabel," or "Anton Dohrn." Occasionally I used grappling-irons, working alone in a punt. In this case I either made the punt stationary to buoys, \&c., and then hurled the grapples as far as possible, drawing them in slowly and with steady motion, or else I fastened the rope of the grapples to the boat, and rowing slowly dragged the grappling. irons for some distance. I used sometimes a small anchor with half a dozen curved, radiating teeth; or, better, grapples of a similar form, but made of soft iron, so that if caught on a rock a vigorous pull bent the iron and released the whole. A straight bar of iron, with a horizontal row of curved teeth on one side, was also very useful. In some localities where Laminaria is growing in plenty, e.g. some parts of Firestone Bay, grappling is better than dredging, for the dredge becomes choked in the first few yards with Lami. naria and nothing can then enter. 


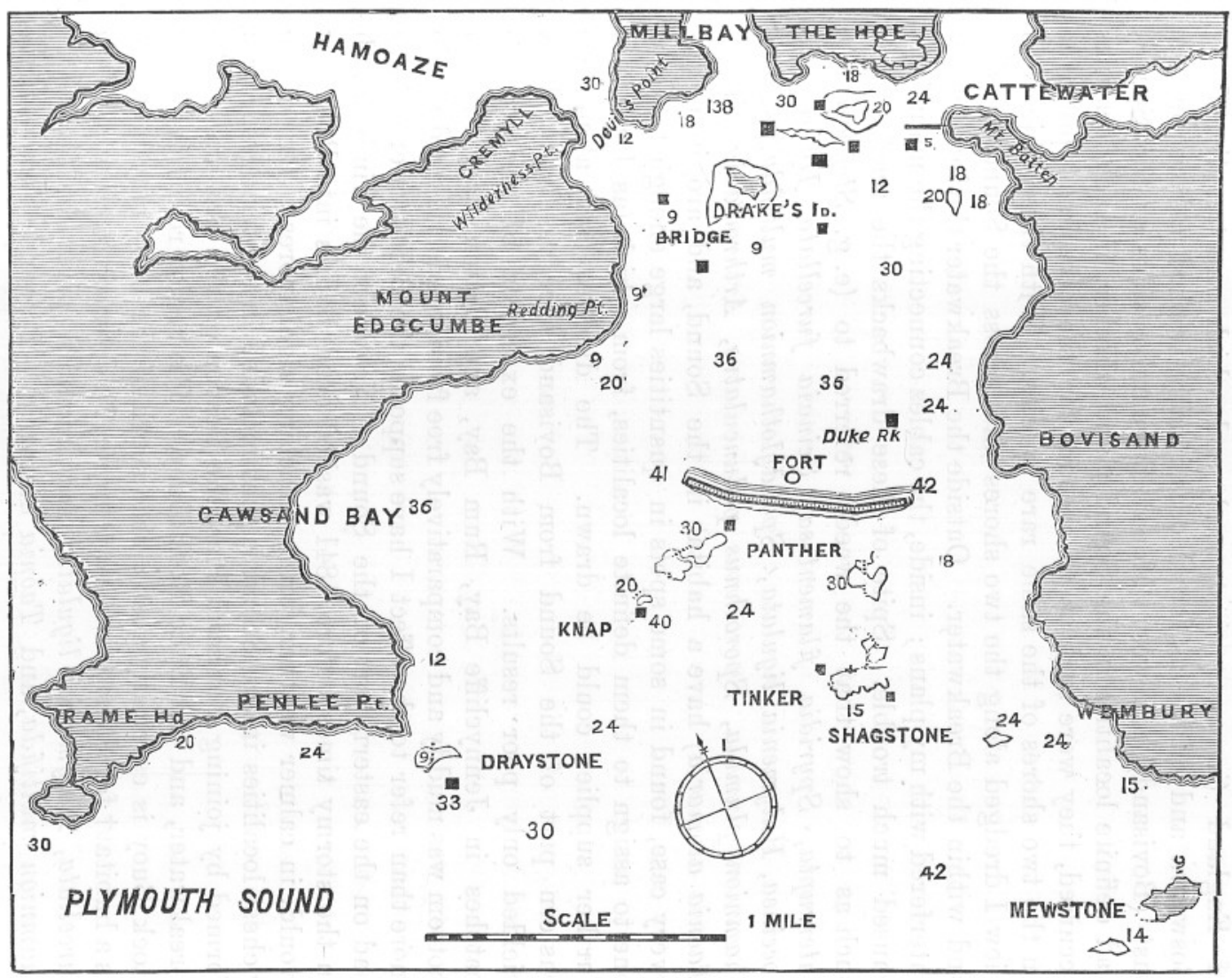

Map of Plymouth Sound, illustrating the localities mentioned in Mr. Johnson's paper 


\section{Dredging Results.}

I was early anxious to ascertain whether the southern and subtropical weeds which reach their northern limit on the south coast of England (in many instances), and which are mentioned by Boswarva and others as found occasionally washed ashore on the east (Bovisand) and west (Mount Edgcumbe) sides of the Sound, had definite localities in the Sound; and whether, if such localities occurred, they were such as to account for the occasional presence on the two shores of the same rare species. With these objects in view I dredged along the two shores and across the Sound, outside and within the Breakwater. Outside the Breakwater the huge rocks interfered with my plans ; inside, the cables connecting the main forts caused much trouble. Spite of these drawbacks the results were such as to show that the weeds referred to (e. g. Stenogramme interrupta, Spyridia filamentosa, Scinaia furcellata, Dudresnaia coccinea, Halymenia ligulata, Spondylothamnion multifida,* Antithamnion plumula, Sporochnus pedunculatus, Arthrocladia villosa, Taonia atomaria) have a habitat in the Sound, and are, in nearly every case, found in some spots in quantities large enough to allow one to assign to them definite localities, from which (as I proved) further supplies could be drawn. The dredge, used along the eastern part of the Sound from Bovisand Pier to Batten Pier, yielded only poor results. With the exception of one or two patches in Jennycliffe Bay, Rum Bay, and Batten Bay, the sea bottom was muddy and comparatively free from weeds. I need not do more than refer to the effect I have supposed the Breakwater to have had on the eastern part of the Sound. No doubt the winds which in the stormy times before 1841 washed dead bodies into Rum Bay would, in calmer weather, bring enriching algal spores. One of the richest localities in the Sound is that included in the triangular area formed by joining Bovisand Pier, the Beacon on the east end of the Breakwater, and the Duke Rock Buoy. The region round the Duke Rock Buoy is especially good ; that south of the buoy may be taken as a habitat† for Stenogramme interrupta, Dudresnaia coccinea, Scinaia furcellata, Halymenia ligulata, Antithamnion plumula, Spondylothamnion multifida, and Taonia atomaria. I found Stenogramme

* I use throughout these pages the specific names employed by Hauck in Die Meeres. algen, 1885 (Rabenhorst's Cryptogamen-Flora, ii).

+ It should be remembered that my personal knowledge was gained in the months of August and September, and that my remarks refer of necessity to these two months. I do not attempt any comparison between the flora of Plymouth, Torquay, Falmouth, and such places. 
interrupta in plenty, tetrasporous, male and female plants, and hope to publish shortly the results of my examination of this interesting plant. Dudresnaia coccinea (tetrasporous and $q$ plants) was also in quantity, and in such a condition as to allow one to follow out all the stages in the strange formation of the cystocarps, first made known by Thuret and Bornet. A month earlier (middle of June to middle of July) would have yielded still better results.

The following are the more important forms met with in the triangular area :

S. interrupta, and the others just named.

Callithamnion seirospermum, and other species.

Antithamnion plumula, $a$ genuinum, and $\beta$ crispum, tetraspores, $q, \delta$, fruits.

Naccaria Wigghii, + , fruit.

Bonnemaisonia asparagoides, 우 fruit.

Delesseria ruscifolia, fruit.

Rhodophyllis bifida, tetraspores, fruit.

Nitophyllum Hilliæ, tetraspores, fruit.

Gracilaria confervoides.

Sporochnus pedunculatus.

Dictyota dichotoma, $\delta,+$, tetraspores.

Sphacelaria cirrhosa.

Striaria attenuata.

Dredging between (1) the lighthouse on the west end of the Breakwater, and Picklecombe Fort on the mainland yielded Halymenia ligulata in abundance, with cystocarps, Scinaia furcellata, Sporochnus pedunculatus, Bonnemaisonia asparagoides, Rhodophyllis bifida, and Dictyota dichotoma, all fertile; and combined with dredging between (z) Queen Ground Buoy, Panther Buoy, and Breakwater lighthouse showed (spite of the nature of the sea bottom, which in some places is very rocky, in others sandy, neither condition being favorable to dredging) that, except for Stenogramme interrupta and Taonia atomaria, the weeds found at the west entrance to the Sound are very much the same as those found in the east entrance (round the Duke Rock Buoy). In all, representatives of at least forty genera (in some cases several species) were found. Monospora pedicellata and $M$. clavata with monospores, Phyllophora rubens with nemathecia, Arthrocladia villosa with zoosporanges, Punctaria tenuissima were met with here, and not in the east entrance.

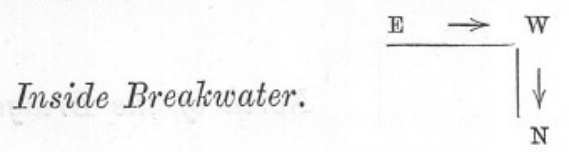

Dredging inside the Breakwater across the Sound, east to west, was, as already said, interfered with by the forts' cables. The weeds found are not improved in quality by the use of this ground as the anchorage for the men-of-war, cinders, \&c., being dredged in 
abundance. Stenogramme interrupta, Dudresnaia coccinea, Scinaia furcellata, Halymenia ligulata, were not met with behind the Breakwater. Near the western buoy Arthrocladia villosa was obtained in quantity. In addition the following more important forms :

Antithamnion plumula, $\beta$.

Callithamnion thuyoideum ( $\delta$, tetraspores), \&c.

Spondylothamnion multifida.

Chantransia virgatula.

Ceramium tenuissimum, fruit, tetraspores.

Nitophyllum punctatum, N. Hilliæ, N. laceratum, N. Bonnemaisoni, $\delta$.

Delesseria alata, D. ruscifolia.
Hydrolapathum sanguineum.

Rhodymenia palmata, R. palmetta, R. ciliata.

Phyllophora membranifolia, P. rubens (fruit).

Dictyopteris polypodioides (a little).

Striaria attenuata.

Desmarestia aculeata, D. ligulata.

Dictyota dichotoma.

Area enclosed by East Winter and other Buoys in Centre of Sound.

Here (the mud "cakey" and a home for nemertians) the following are the more important forms observed:

Antithamnion plumula.

Monospora pedicellata.

Chrysymenia rosea.

Chylocladia clavellosa.

Lomentaria corallina.

N. punctatum.

The western part of the Sound, from Picklecombe Fort in the sonth to the bridge on the Mount Edgcumbe side in the north, is too dangerous for any nearer examination in the "Firefly" than that part marked out in the Admiralty chart as the regular passage to the Hamoaze. The bridge itself is covered with Rhodymenia palmata and Laminaria digitata, only a few other, and these common, forms being found. L digitata is well exposed at low tide, thus illustrating a statement of Cocks, made twenty years ago, that this plant was gradually taking up a littoral position, and ceasing to be met with only as an extra-tidal weed.

\section{North of the Bridge.}

Dredging here showed a poor flora, the strong currents, no doubt, being to a very great degree-accountable. It was of interest to find, though as scraps only, S. interrupta, Chrysymenia rosea, and Dudresnaia coccinea. 


\section{Barn Pool.}

Owing to the very strong currents, dredging here is not possible, except for an hour before and after the turn of the tide. The results, so far as seaweeds are concerned, were negative, ${ }^{*}$ the dredge, in the parts nearer the shore, filling each time with large stones covered with ascidians.

\section{The Hamoaze.}

Owing to the extremely muddy nature of the bottom of the Hamoaze, dredging, except in one or two localities, is almost useless. The dredge quickly fills with mud, in which only a few weeds, not essentially different from the adjacent shore forms, are found imbedded, and not until much washed, fit for examination. The bottom of the Hamoaze, along the Royal Victualling Yards and along the building sheds, is not muddy-indeed, in the latter region it is very rocky in places, but yields weeds of the commoner kind only. Shore-hunting, either on foot, when one must be prepared to sink ankle-deep in mud, or better, in a punt, is the most successful mode of examination. Mr. Holmes has made many interesting "finds" at Torpoint. Owing to the regulations affecting the approach of steamers to the powder magazines, I was not able to take more than three or four dredgings off St. Peter's Point. Shore-hunting on foot at the Point itself is full of interest, but very disagreeable. On the Saltash side of the Point the beach is stony for a short distance, and here it is useful to wade at low spring tide, and to pick up, in the muddy water, stones which will be found, in many cases, covered with delicate, filamentous, red weeds. Nearer Saltash it is necessary to take to the punt and to continue the shore examination in it, as the rocky beach ends abruptly, and wading is impossible. In the following list I give only the more important of the locally established weeds, making no mention of the many evidently Sound-drifted ones :

Delesseria hypoglossum, in all conditions, in abundance.

Griffithsia corallina, tetraspores, ơ, + .

G. setacea.

G. devoniensis.

Antithamnion plumula, $\beta$, $q$, \&c.
Dasya ocellata.

Callithamnion seirospermum, C. gracillimum, \&c.

Chylocladia clavellosa, tetraspores, + .

Chondrus crispus.

Species of Ulva and Enteromorpha, abundant.

* This was the more disappointing, as I hoped to find the rare weed Carpomitra Cabreræ, which twenty years ago was found by Cocks established on Mount Edgeumbe mud-bank. 
The preceding forms were, on the whole, better represented on the rocky beach.

\section{Beggar's Island (Rat Island).}

No algologist visiting Plymouth should omit to examine Beggar's Island and the region round St. Peter's Point, just described. Beggar's Island at low spring tide, on its west and south-west sides, presents a most interesting sight of weeds growing in brackish waters.* The more interesting forms found were-

Antithamnion plumula, $\beta$, very

fine plants.

Griffithsia corallina.

Pleonosporium Borreri.

Dasya ocellata, D. coccinea.
Polysiphonia, several species.

Halymenia ligulata, several pieces, probably drifted.

Ectocarpus siliculosus, E. tomentosus, \&c.

\section{Firestone Bay.}

I have already mentioned how poverty-stricken the beach here is, the shore embankment, \&c., being covered with the commoner species of Fucus, Ascophyllum nodosum, Rhodymenia palmata, Gigartina mamillosa, Ectocarpus, \&c. I saw no signs of such rare forms as Crouania attenuata, Arthrocladia villosa, Spyridia filamentosa. In the extreme south-west of Firestone Bay, just off the beach, the dredge mouth became choked almost at once with Laminaria digitata. Deeper in, and in a north-easterly direction, the results are better, including-

Stenogramme interrupta, tetraspores, $q$.

Spondylothamnion multifida, fruit.

Antithamnion cruciatum.

A. plumula, $\beta$.

Chylocladia clavellosa, fruit.

Bonnemaisonia asparagoides.

Monospora pedicellata.

Delesseria hypoglossum, D. ruscifolia.

Rhodymenia laciniata, $\uparrow$ fruit.

I dredged in this bay a Crouania-like plant which seemed to

\footnotetext{
* Care must be taken in passing from the west to the less interesting central and eastern
} parts. Several times I sank knee-deep in mud.

+ Miss A. L. Smith, of the Normal School of Science, is at present engaged on the examination of the development of the fruit of $R$. laciniata, and has already obtained many interesting results. 
agree with Kützing's genus Sporacanthus. Through the kindness of the distinguished algologist, Dr. E. Bornet, I am able to say that it is a form of Antithamnion cruciatum, with pentamerous whorls of ultimate simple acicular branches, on which the scooped-out intercalary tetraspore-like bodies are reserve-spores according to the observations of Berthold.* Dr. Bornet sent me a plant of $A$. cruciatum, dredged at Antibes, having both tetraspores and reservespores.

\section{Drake's Island.}

The shore of the greater part of this island is not rich in weeds. In the extreme south-west I found Bryopsis plumosa growing in half a dozen balf-tide rock-pools-the best locality in Plymouth Sound for this weed. The south-west rock-pools are fairly rich, the weeds, for the most part, like those found on the north-east and east shores, the more important forms being-

Gigartina mamillosa, in great abundance.

Lomentaria ovalis, $q$, tetraspores.

Chylocladia articulata.

Gracilaria confervoides.

Chondrus crispus.

Porphyra.

Dictyota dichotoma.

Desmarestia.

Dredging and grappling combined showed the region north and north-west of Drake's Island to be surprisingly rich in weeds, as the accompanying list will indicate:

Stenogramme interrupta, fruits, in abundance.

Dudresnaia coccinea.

Sphærococcus coronopifolius. Gracilaria confervoides.

Griffithsia corallina.

Antithamnion plumula, $\beta$. Callithamnion, several species. Bonnemaisonia asparagoides.

Ceramium tenuissimum.

Sarcophyllis edulis.

Phyllophora membranifolia (P.

palmettoides ?).

Rhodophyllis bifida, fruit.

Nitophyllum venulosum (N.

thyrsorhizans of Holmes).

$\mathrm{Up}$ to the present the different observers of fertilization in the Cutleriacer have failed to observe the nucleus in the ovum. I am

* Berthold, U. d. Vertheilung d. Algen, i, S. v, Neapel.
N. laceratum.

Rhodymenia laciniata.

Chylocladia articulata.

C. clavellosa.

Gigartina mamillosa.

Gelidium corneum.

Dasya coccinea (almost everywhere).

Cutleria multifida, + .

Dictyopteris polypodioides.

Taonia atomaria.

Dictyota dichotoma.

Asperococcus compressus.

Scytosiphon lomentarius.

Cladostephus, Sphacelaria, Ectocarpus, Cladophora, species. 
about to publish the results of an examination of the ova of Cutleria multifida at the time of fertilization, my examination by means of the microtome leading me to say that the ovum is, as to be expected, nucleated. Hence, if I am correct, a re-examination of the process of fertilization in the Cutleriacex, in which account will be taken of the behaviour of the $q$ pronucleus, is necessary. I propose to use the microtome in the examination of the ova of other brown seaweeds, making use of much the same method as that which has been so successfully employed in the investigation of the maturation, \&c., of the animal ovum.

I was quite unsuccessful dredging off the entrance to Mill Bay, the inner waters of which I did not examine. Dredging off the Laboratory, and in an easterly direction towards Batten, the specimens found were generally small and dirty, especially in Batten direction.

The chief forms found were-

Halymenia ligulata (a little).

Nitophyllum seirospermum, N.

punctatum.

Rytiphlæa complanata.

Callithamnion, several species, including C. thuyoideum.

Antithamnion cruciatum, A. plumula.

Bonnemaisonia asparagoides.

Sarcophyllis edulis.

Kallymenia Dubyi.

Gigartina mamillosa.

Gracilaria confervoides.

Rhodophyllis bifida.

Rhodymenia laciniata, R. ciliata, R. palmata.

Delesseria alata, D. hypoglossum, D. ruscifolia.

Chylocladia clavellosa, C. articulata.

Monospora pedicellata.

Chantransia virgatula.

Gelidium corneum.

Ceramium diaphanum.

Punctaria, Desmarestia, Chorda filum.

Laminaria saccharina.

Bryopsis plumosa is found in several pools on the beach below the Laboratory, immediately east of the ladies' bathing-place. In one plant found here I saw zoospores, without, however, being able to bring about the dehiscence of the zoosporange.

\section{The Laira.}

Dredging in the Laira, as in the greater part of the Hamoaze, is, owing to the mud, out of the question. Under the Laira railway bridge, at the bases of the pillars, the genera Ulva and Porphyra are to be found in great plenty. The mud-banks above the railway bridge were, owing to the thick deposit of china clay works' refuse, too soft for extensive searchings on foot. I found it necessary to stay in the punt, and to pick up with the boat-hook as I moved 
along any weeds required. The brackish waters of the Laira are not so rich as those off St. Peter's Point and Beggar's Island in the Hamoaze. I found-

Antithamnion plumula, $\boldsymbol{\alpha}$ and $\beta$.

Delesseria hypoglossum.

Species of Callithamnion, Poly-

siphonia, and Ceramium.

I must have overlooked Griffithsia. Leaving the Laira, one may find, on the projecting end of Batten Pier amongst other plants, Antithamnion plumula, $\beta$, and Callithamnion gracillimum; and in Batten Bay, in the region of the Cobbler Buoy,-

Callithamnion thuyoideum.

Pleonosporium Borreri.

Pylaiella littoralis.

Ectocarpus tomentosus.

Antithamnion cruciatum.

Monospora pedicellata.

Rhodymenia palmata, R. laciniata, R. palmetta.

Rhodophyllis bifida.

Chylocladia claveilosa.

Stilophora rhizodes, 1-loc. and

8-loc. sporangia.

Bryopsis plumosa.

I propose now to consider that part of the Sound which is on the English Channel side of the Breakwater, and to begin with-

\section{Cawsand Bay.}

This bay, especially in its south-west part, is pre-eminently the habitat for Spyridia filamentosa and the different species of Ceramium. The sandy rock-pools with stones in them, on the north side of the bay from Picklecombe Fort westwards, are especially good, and provide one of the best localities in Plymouth for the examination of littoral weeds, the following amongst others being found here:

Gracilaria confervoides, in abundance.

Polyides rotundus.

Fastigiaria furcellata.

Rhodomela subfusca.

Dasya arbuscula and D. coccinea.

Chylocladia, Ceramium, Polysiphonia, Callithamnion.

Rhodymenia, species.

Gelidium corneum.

Gigartina mamillosa.

Very little Delesseria or Nitophyllum.
Chantransia virgatula.

Gymnogongrus plicatus.

Porphyra.

Scytosiphon lomentarius.

Asperococcus.

Pylaiella littoralis.

Myriotrichia clavæformis, 1-loc. sporangia.

Sphacelaria, Cladostephus, Desmarestia aculeata.

Ectocarpus, Ulva, Enteromorpha, Cladophora.

Bryopsis plumosa.

Shore-hunting on the south side can scarcely be carried on at all except in a boat, and the flora is not rich in variety, Laurencia, Chylocladia, Polysiphonia, Ceramium, being the more important 
genera represented. Dredging in Cawsand Bay yields a rich harvest of interesting forms, including in the north part of the bay-

Stenogramme interrupta.

Spyridia filamentosa, tetraspores, + .

Dudresnaia coccinea, tetraspores, $q$.

Halymenia ligulata.

Naccaria Wigghii, fruit.

Spondylothamnion multifida.

Sarcophyllis edulis.

Gracilaria confervoides.

Phyllophora, Fastigiaria, Rhodomela, Delesseria.

Ceramium, Dasya, Gelidium, species.

Rhodymenia jubata and other species.

Rhodophyllis bifida.

Gigartina mamillosa.
Callithamnion seirospermum and other species.

Antithamnion plumula, $\alpha$ and $\beta$, $\delta$, o.

Chantransia virgatula, $\delta$, $q$.

Chylocladia parvula.

Arthrocladia villosa.

Sporochnus pedunculatus.

Sphacelaria cirrhosa, and pennata with propagula and sporangia.

Asperococcus compressus, with sporangia.

Scytosiphon lomentarius.

Chorda filum.

Dictyopteris polypodioides.

Ulva, Enteromorpha, Cladophora.

I found no better dredging locality for the different species of Ceramium than that between North Point and Pier Cove, in the 2-4 fathoms limit as indicated on the Admiralty chart. In this part and towards Penlee Point Zostera beds are plentiful, affording anchorage for different algæ. I was pleased, too, to find a definite locality for the rare (Plymouth) weed, Spyridia filamentosa. Most of the specimens found were tetraspore-bearing plants (a good sign so far as the propagation of the species is concerned); $\delta$ and $q$ plants were also found in sufficient quantities to permit one to work out in detail the sexual organs and fruit formation. The dredge should be used in the " $1 \frac{3}{4}-2 \frac{1}{4}$ " fathoms belt, as near in to the rocks as possible, immediately south of Cawsand landing beach, and on the shore side of any moored boats. Cawsand Bay is not one of the easiest waters in which to dredge; on the south side the boat-anchors are very troublesome, and on the north side there is a very rocky shore with many submerged rocks close in. In addition to many of the species of Ceramium and Spyridia filamentosa, Callithamnion seirospermum, C. gracillimum, Antithamnion cruciatum with reserve-spores, Phyllophora rubens, and the more important (though by no means all) of the weeds found in the north part of the bay, e.g. Halymenia ligulata, Dictyopteris polypodioides, Gracilaria confervoides, Pylaiella littoralis, Ectocarpus siliculosus, were dredged in the southern part of the bay. 


\section{Rame Head to Penlee Point.}

This part of the coast is fully exposed; the rock-pools are not good, numerous, or easily approached. In a cove south of Eastern Gear I found scarcely one filamentous weed, membranous weeds only. Dredging showed, on the whole, a similar general scarcity or absence of weeds. Hydrolapathum sanguineum is especially abundant here. In addition I found-

Bonnemaisonia asparagoides. Spondylothamnion multifida, in plenty.

Antithamnion plumula, $a$ and $\beta$, in plenty.

Delesseria alata, D. ruscifolia. Sarcophyllis edulis.

Dictyopteris polypodioides and pennata.

Sphacelaria cirrhosa.

Cladostephus, Ectocarpus, and several others $(6-8)$ common genera.

\section{Whitsand Bay.}

Owing to the very sandy nature of the bottom of this bay, and the scarcity of weeds, the dredge is of very little use, digging into and filling with sand in a few yards, with a resulting stoppage of the steamer if slowly moving. In the extreme east of the bay the ground is very rocky, and, owing to weather and want of time, my work here was confined to the shore weeds. Nowhere did I find more driftweed, and probably after a storm a rich harvest would be reaped in Polhawn Cove, below the Coastguard Station. The rock-pools are good, and well stocked with most of the weeds to be met with in the littoral zone of Plymouth waters, well repaying examination. The beach, 300 yards west of Polhawn Cove, is very barren for miles. Time after time the dredge when hauled in showed only one or two weeds, and had I relied for my conclusions on the contents of the dredge, I should have supposed that only very few weeds were present in Whitsand Bay, and that these were confined to half a dozen genera (excluding from this generalisation the unexamined eastern part of the bay). Fortunately I was allowed to overhaul the trawl of the "Penguin," after a run from west to east of the bay (nearly three miles).

On this trawl I found representatives of at least forty genera. I took off every weed on the trawl for detailed examination later. The weeds from this trawl, with a fifteen-foot beam, after a run of nearly three miles, occupied no more space than those taken in Cawsand Bay in the dredge after a run of $30-40$ yards. T'he more interesting forms trawled were- 
Stenogramme interrupta, 4spores, $q$.

Phyllophora rubens.

Polyides rotundus.

Spondylothamnion multifida.

Antithamnion plumula, $\beta, \mathrm{A}$. cruciatum.

Bonnemaisonia asparagoides.

Hydrolapathum sanguineum.

Rhodomela subfusca.
Gracilaria confervoides.

Cutleria multifida.

Dictyopteris, ô, $q, 4$-spores.

Dictyota dichotoma.

Sporochnus pedunculatus.

Arthrocladia villosa.

Desmarestia ligulata, D. aculeata.

Sphacelaria filicina.

Fucus canaliculatus.

It is naturally impossible to say at what particular point in the three miles course the different weeds were gathered by the trawl. Later in the same day the "Penguin" trawled inside the Sound from the Breakwater lighthouse to Batten Pier, and on the trawl many of the rarer weeds, previously described as growing in the Sound, were found, but in what particular locality they were taken up it is not possible to say. Such weeds were Spyridia filamentosa (the only time I found it in the inner part of the Sound), Stenogramme interrupta (in abundance), Nitophyllum Bonnemaisoni and N. Hillix, Scinaia furcellata, Sphærococcus coronopifolius, Griffithsia corallina, Arthrocladia villosa, Dictyopteris polypodioides.

\section{Bovisand Bay.}

The local interpretation of "Bovisand Bay" is much wider than that sanctioned by the Admiralty chart. Locally, one understands the waters between Staddon Point in the north, Renny Point and the Shagstone in the south. The beach of Bovisand Bay proper ordinarily presents but few weeds; after a storm the weeds, it is said, lie ten to twelve feet thick, tons being carted away as manure. Between Andern Point and Renny Point, especially in the immediate neighbourhood of Renny Point, the rock-pools are well stocked with various weeds, including Nemalion multifidum, Chylocladia articulata, Lomentaria kaliformis, Ceramium acanthonotum, C. ciliatum, and species of Chantransia, Griffithsia, Rhodomela, Laurencia, Delesseria, Gymnogongrus, Spondylothamnion; Ptilota elegans (in great abundance), Gelidium corneum (several varieties, in plenty), Mesogloea vermiformis, Dictyota, Ectocarpus, Cladophora, Bryopsis plumosa.

Dredging in the waters between Staddon Point and Renny Point brings to light many interesting plants, which, taken in connection with those dredged round the Duke Rock Buoy, readily explain the occasional finding, as cast-up weeds, of Stenogramme interrupta, Spyridia filamentosa, \&c. I dredged in Bovisand Bay at least 90 of the 350 species found in Devonshire waters, including- 
Stenogramme interrupta.

Spyridia filamentosa.

Dudresnaia coccinea.

Scinaia furcellata.

Microcladia glandulosa.

Nitophyllum versicolor, Hilliæ, laceratum, punctatum.

Phyllophora Brodiæi, palmettoides, rubens, membranifolia.

Rhodymenia laciniatar, ciliata, palmata.

Rhodophyllis bifida.

Chylocladia articulata, parvula, clavellosa.

Lomentaria kaliformis, ovalis.

Delesseria alata, ruscifolia, sinuosa, hypoglossum.

Hydrolapathum sanguineum.

Gracilaria confervoides.

Polyides rotundus.

Fastigiaria furcellata.

I found Bovisand Bay the best locality for Nitophyllum and Phyllophora.

\section{Wembury Bay.}

Passing south-east from Renny Point one comes to a number of fine rock-pools, the ridge on which they occur running out from the mainland so as to join, within a few yards, the outlying rocks of the Mewstone. The passage left is so narrow and shallow that in the lowest spring tides one can, I am told, wade across. Many of the rock-pools are sandy, and have excellent Zostera beds. I do not know any more instructive locality in Plymouth waters for shorehunting than Wembury Point.

Cystoclonium purpurascens and

$\beta$ cirrhosa,

Rhodymenia jubata and $\beta$

cirrhosa,

not to mention others, were all found in plenty.

On the rocks east of this reef the marine lichen Lichina pygmæa grows abundantly at half-tide. The rock-pools below Wembury Church are also full of interest, and amply repay examination. Here were growing in plenty Gigartina pistillata in fruit, Monospora pedicellata, Corallina rubens and $\beta$ corniculata, Gymnogongrus plicatus, Chordaria flagelliformis, Codium tomentosum.

NEW SERIES.-VOL. I, NO. III. 
Wembury Bay itself abounds with submerged rocks, and a thorough knowledge of its topography, as Roach had, is necessary in dredging. There is no better locality for the Phæophyceæ and the Corallinacer than Wembury Bay. Chief weeds found :

Corallina officinalis, squamata, rubens, and $\beta$ corniculata.

Gracilaria confervoides.

Rhodymenia jubata.

Fastigiaria furcellata.

Bonnemaisonia asparagoides. Species of Callithamnion, Rhodomela, Polysiphonia, and Lomentaria.
Delesseria alata, D. sinuosa.

Dictyopteris polypodioides.

Dictyota dichotoma.

Taonia atomaria.

Sporochnus pedunculatus.

Mesoglœa, Sphacelaria, Cladostephus, Punctaria, Leathesia species.

\section{The Mewstone.}

The rock-pools of this interesting rock are well worth a visit; protected on the north side and close to the mainland, they are on the south side, for the most part, exposed to and in connection with an open sea. They are richest in the north, north-east, and southwest parts, and, as would be expected, the weeds found in the north and north-east pools are much the same as those found on the mainland opposite. I was pleased to find here a very fine plant of Codium tomentosum bearing zoosporanges, the whole plant a single multinucleate cell, weighing at least three pounds !

Polyides rotundus.

Sarcophyllis edulis (in plenty).

Dasya ocellata.

Nitophyllum Hilliæ, N. punctatum.

Rhodophyllis bifida.

Antithamnion plumula.

Gigartina mamillosa.

Nemalion multifidum.

Gelidium corneum, several varieties (four or five in one pool).

On the south and south-west parts, in addition to most of the foregoing, the following amongst others were found :

Delesseria hypoglossum, D. ruscifolia.

Cystoclonium purpurascens.

Phyllophora rubens.

Spondylothamnion.
Gymnogongrus plicatus.

Several species of Callithamnion (including C. polyspermum), Polysiphonia, Ceramium.

Cutleria multifida, $q$, and Laminaria bulbosa, drifted.

Dictyota, in plenty.

Desmarestia, Sphacelaria, Cladostephus, Ectocarpus, Bryopsis, \&c., were found here.
Fastigiaria.

Laurencia.

Chylocladia.

Rhodymenia.

Bangia. 
Porphyra.

Mesoglœa (in plenty).

Asperococcus.

On a calm day one can see the bottom of the sea, even to the recognition of particular weeds, in many places in Wembury Bay, north and east of the Mewstone. Circumstances prevented me from carrying out an intention of using the dredge or grapples in these places. Dredging half a mile south of the Mewstone, in seven to nine fathoms, 200-400 yards east of the Black Buoy, revealed the rare (British) weed Dictyopteris polypodioides in great abundance, with tetraspores, $q$ and $\delta$ organs. I read a paper on this genus before the Linnæan Society in December last, in which paper the results of my examination of this Plymouth material were incorporated. I was able to show that the Dictyotaceæ are true Phæophyceæ, and that they fall into a series in which Reinke's Tilopterideæ, of which the Plymouth representative is Tilopteris Mertensii, are included. Other weeds dredged here were-

Rytiphlæa fruticulosa.

Scinaia furcellata.

Bonnemaisonia.

Schizymenia.

Rhodymenia jubata.

Corallina rubens.
Gracilaria confervoides.

Delesseria sinuosa.

Gelidium corneum.

Cutleria multifida.

Sporochnus pedunculatus.

Taonia, Dictyota, Cladostephus.

\section{Mouth of the Yealm River.}

Dredging in the Yealm in three to six fathoms, off the Coastguard Station and close in, furnished a locality for Gracilaria multipartita (G. polycarpa), Halymenia ligulata, Scinaia furcellata, Dudresnaia coccinea (all in abundance). The following were also dredged :

Spyridia filamentosa, $\quad$ Asperococcus bullosus, Gracilaria confervoides, $\quad$ Sporochnus pedunculatus, and species of Monospora, Antithamnion, Spondylothamnion, Delesseria, Nitophyllum, Rhodophyllis, Gymnogongrus, Chylocladia, Ceramium, Ectocarpus, \&c.

\section{The Breakwater.}

I was prevented from examining the Breakwater at all fully. On the inner side the boulders, \&c., were seen, at low spring tide, covered with Fucus, Ozothallia, Laminaria, Halidrys, growing amongst which were Gigartina mamillosa, species of Callithamnion, including C. seirospermum, Ceramium, Chylocladia, Plocamium, 
Rhodymenia, Pylaiella littoralis, Scytosiphon lomentarius, Bryopsis plumosa.

Middle Fort (behind Breakwater).

Examination of the inter-tidal and extra-tidal surface of this fort brought to light Spondylothannion multifida (very fine plants), several species of Callithamnion, including C. thuyoideum, C. seirospermum, C. gracillimum, Antithamnion plumula, $\beta$, species of Nitophyllum, Gigartina, Rhodymenia, Delesseria, Chylocladia, Porphyra, Desmarestia, Ectocarpus, Ulva, \&c.

\section{The Buoys.}

Examination of the buoys, with which Plymouth waters abound, serves to give one some idea of the migrations of marine plants. It should be remembered that all the buoys are thoroughly cleaned and repainted twice a year (before and after winter-end of September, beginning of April). They might be used, coated with different substances, for experiments having as their object the discovery of the best weed-growing preventatives as applied to ships' bottoms. The weeds were generally healthy, in full fruit, and firmly attached. Those on the White Buoy, south-south-west of Drake's Island, were relatively poor and insecurely attached.

\section{Draystone Buoy (off Penlee Point).}

It was of interest to find plants of Rhodymenia palmata, for in this species no British fruit-bearing specimen has yet been found, only tetraspore-bearing forms.

Amongst others on the buoy were Chantransia, Polysiphonia, including P. Brodiæi (the tufted branches of which form nests for Isopoda), Punctaria, Scytosiphon, Sphacelaria, Ectocarpus, Ulva, Enteromorpha. The weeds growing on the buoys outside the Breakwater, marking the east and west channels for vessels, included those found on the Draystone Buoy, and, in addition, Bangia fusco-purpurea, Ceramium rubrum, Callithamnion, Laminaria saccharina, Desmarestia ligulata. The weeds on the Duke Rock Buoy were similar to those on the outer buoys, but less abundant.

Desmarestia.-With the exception of a brief notice in Etudes Phycologiques by Thuret and Bornet (p. 16) of unilocular sporangia in Desmarestia viridis, no description of reproductive organs in any species of Desmarestia has yet appeared. On a small plant of Desmarestia ligulata I was fortunate enough to find (after examining every plant of Desmarestia met with during my stay) unilocular, 
usually monosporous sporangia in the position in which Harvey nearly fifty years ago suggested, and in the cortex too. I hope to publish shortly a detailed description.

\section{Bigbury Bay.}

The rocks south of Yealm River mouth towards Stoke Point, fully exposed to the south-west gales, were generally barren like those between Rame Head and Penlee Point. East of Revelstoke Point, and well protected by it, there are good, well-stocked rock-pools. A short visit to the pools west of Revelstoke Church led me to think the weeds generally comparable to those found on the Renny Rocks, Wembury Point, and the Mewstone. Cystoclonium purpurascens, Sarcophyllis edulis, Monospora, Griffithsia equisetifolia, Ptilota elegans, Mesogloea vermiformis, and many others were seen. The dredge brought up Phyllophora rubens with nemathecia, Spondylothamnion multifida, Antithamnion plumula, Bonnemaisonia asparagoides, Dictyopteris polypodioides, Sphacelaria filicina, \&c.

I propose in a subsequent number of the Journal to continue my observations on the flora, to give a more detailed list of the species met with, and to trace out the distribution, in the different localities, of individual species. I have, I trust, said enough to show that there is no lack of algæ needing investigation. It is impossible for me to give an adequate idea of the details of the flora. I shall be only too pleased to place my knowledge, gained under such great advantages, at the service of algologists. 